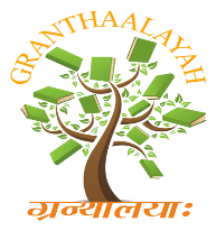

\author{
INTERNATIONAL JOURNAL OF RESEARCH - \\ GRANTHAALAYAH \\ A knowledge Repository
}

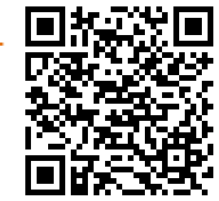

\title{
SOCIAL PROBLEMS AND ENVIRONMENT
}

\author{
Neeta Tiwari
}

H.O.D. Sociology Dept. Govt. Girl's P.G. College, Ujjain, (M.P.)

\begin{abstract}
With ever increasing social and environmental problems, the principles of Socio-Economic Sustainable development have gained prime importance. Human activities and their after-effects, direct and indirect, strongly influence nature and its resources. Keeping the huge role played by mankind in sustaining the glory of nature in mind, development goals need to be shaped in accordance with the parallel development and benefit of nature. India, as a developing nation, has a landmark role to play in future ecology conservation and management.
\end{abstract}

Keywords:

Environmental degradation, Human-nature interaction, Socio-economic development, Development plans, Indian contribution.

\section{INTRODUCTION}

India is the largest contributor to world population growth, adding about 17 million people every year to an already huge population of over one billion. Although more than two-thirds of India's population still lives in the rural areas, it has experienced rapid urbanization over the last two decades. India has attained food sufficiency in spite of its growing population. It has also created a large base of skilled scientific and technical human resources with a diversified industrial base. However, the benefits of this impressive growth have been substantially offset by environmental degradation. Even though India has a rich tradition of environment conservation, large scale environment degradation has resulted from population pressures, industrialization and the indiscriminate use of forest areas for fuel, power generation and irrigation purposes.

Various human activities have induced many undesirable effects to the environment which can be threatening human health, economic, natural resources and gene pool of ecosystems such as pollutions, greenhouse effect, global warming and soil erosion.

Activities of man right from birth to death on this earth are deeply related to social issues. He while living in society cannot detach himself from social issues of life. This is the reason that someone has rightly pointed out that society is the web of social relations and man is social animal. Social issues cover family, associations, institutions and communities. Perhaps family is the strongest agency of social issues. While being in society he has to undertake a number of socio-economic activities such as industry, agriculture, transport, construction of roads, and buildings etc., for surviving in the society. These activities contribute much too environmental degradation (the act of lowering) including water, soil and air etc. Socio-economic development is the call of the day because everyone desires to have a higher and better standard of living. The geographical land area with man is reducing day by day due to 
growing population. With the limited availability of land for cultivation purposes, the need for increasing the application of fertilizers: nitrogenous, phosphate and potash and also necessary for appropriate pest control through pesticides is being made in order to ensure more and more growth of both food and fiber. These socio- economic activities hit environmental conditions. So the protection of the environment is an important issue of the day.

There should be development without polluting the environment. Sustainable development has been defined as "Development that meets the needs of the present without compromising the ability of future generations to meet their own needs" (The World Commission on Environment and Development, Brundtland Commission 1987). In other words, when people make decisions about how to use the Earth's resources such as forests, water, minerals, wildlife, etc. they must take into account not only how much of these resources they are using, what processes they used to get these resources, and who has access to these resources.

Are enough resources going to be left for our future generations to use and will the environment be left as we know it today?

Therefore, development plans have to ensure: sustainable and equitable use of resources for meeting the needs of the present and future generations without causing damage to environment. The primary objective of sustainable development is to reduce the absolute poverty of the world's poor through providing lasting and secure livelihoods that minimize resource depletion, environmental degradation, cultural disruption and social instability. It also considers the equity between countries and continents races and closes, gender and ages. It includes social and economic development. It is a process which leads to a better quality of life while reducing the impact on the environment.

Practicing sustainable development poses a challenge because people must learn to live on the world's ecological interest and not on ecological capital.

But who pays for the cost of environmental degradation? Most sections of society do not feel the direct effects of degradation of the environment till it is too late. Those who suffer most are the poor, especially rural women, and tribal people who are dependent on forests. Traditional fishermen who are dependent on streams and rivers, and coastal people who fish and catch crustaceans, are seriously affected by the degradation of aquatic ecosystems. Fuel wood gatherers from different types of forests, and pastoralists who are dependent on common grazing lands suffer when their resources are depleted. While the rural people have a deep insight on the need for sustainable use of natural resources and know about methods of conservation, there are however several newer environmental concerns that are frequently outside their sphere of life experiences. Their traditional knowledge of environmental concerns cannot be expected to bring about an understanding of issues such as global warming, or problems created by pollution, pesticides, etc. These people thus require a different pattern of environment education that is related to their gaps in information like locale specific environment awareness programs designed specifically for rural school children and adults. This must also use their local traditional knowledge systems as a base on which modern concepts can be built, rather than by fostering concepts that are completely alien to their own knowledge systems. An amalgamation of the modern and the old, the urban and the rural, the traditional and the scientific ideas is required to make sure that our environment retains the glory that is inherent in it.

\section{CONCLUSION}

Many a times the question comes to our mind as to whether we want environment or development. 
To this the straight reply is that, there should be development within the environment. One does not place these two things separately, viz., development and clean environment. The real socioeconomic development does not lie in producing and collecting material and non-material things but in having these things along with a clean and pollution free environment. It is indeed true...that with changing times the responsibility of steering the development and growth of nature will lie in the hands of developing nations, newborn powers progressing towards a higher economic future. Thus, India has a huge role to play in protecting the future environment. It is a role which will determine the future of global welfare and ecology. Thus, we must remember that with the tide of time, environmental protection and economic development will have to sail forward hand in hand, advancing humanity to a much anticipated and bright future. 